\title{
Nomenclatural note - spelling correction on an epithet in Coulteria (Leguminosae: Caesalpinioideae)
}

\section{S. Sotuyo ${ }^{1}$ (D) J. L. Contreras-Jiménez ${ }^{2}$ (i) \& M. d L. Rico-Arce ${ }^{3,4}$ (i)}

Summary. An orthographic correction for a Coulteria species epithet is formalised.

Key Words. Fabaceae, Mexico, nomenclature.

Following the preparation of a synopsis of the genus Coulteria (Sotuyo et al. 2017), specimens that were different to Coulteria platyloba (S.Watson) N.Zamora group were found. Hence Coulteria lewisiae Sotuyo \& J.L.Contr. a new endemic species to Mexico was recently described (Sotuyo \& Contreras-Jiménez 2021). We are embarrassed that being so involved in the spotless description, type citation and conservation assessment of the species, we failed on the spelling for the epithet, which we herein correct and formalise:

Coulteria lewisii Sotuyo $\mathcal{E}$ J.L.Contr., Phytotaxa 498 (3): 220, Figs 1 - 2 (2021). Type: México, Guerrero Municipio de Zirándaro: $3 \mathrm{~km}$ al $\mathrm{O}$ del Guariche, 21 Sept. 1989, alt c. 240 m, J. L. Contreras 25358 [fr] (holotype FCME; isotypes FCME, MEXU).

http:/ /www.ipni.org/urn:lsid:ipni.org:names:77217198-1

The epithet properly honours Dr Gwilym P. Lewis (he/him) who has spent more than 40 years working with Legumes, trained many undergraduates, gradu- ates and colleagues on legume taxonomy, fieldwork, and herbarium curation. We would like to take this opportunity to congratulate Dr Lewis for being Coordinator for the World legume species checklist at the Royal Botanic Gardens, Kew.

We are grateful to the botanist who called the error to our attention.

\section{References}

Sotuyo, S., Contreras-Jiménez, J. L., Gagnon, E. \& Lewis, G. (2017). A synopsis of Coulteria (Leguminosae), including new names and synonyms. Phytotaxa 291 (1): 33 - 42. https://doi.org/ 10.11646/phytotaxa.291.1.3 \& _ (2021). Coulteria lewisiae (Leguminosae: Caesalpinioideae) a new species for Infiernillo region, Mexico. Phytotaxa 498 (3): 220 - 226. https://doi.org/10.11646/phytotaxa.498.3.8

\section{Publisher's Note}

Springer Nature remains neutral with regard to jurisdictional claims in published maps and institutional affiliations.

\footnotetext{
Accepted for publication 28 May 2021. Published online 23 July 2021

1 Departamento de Botánica, Instituto de Biología, Universidad Nacional Autónoma de México, Circuito Exterior s/n, Ciudad Universitaria, Copilco, Distrito Federal. C.P. 04510, Coyoacán, A.P, 70-367, México. e-mail: jssotuyo@ib.unam.mx

2 Facultad de Arquitectura, Benemérita Universidad Autónoma de Puebla, 4 Sur 104. Col. Centro. CP 72000, Puebla, México.

3 Comisión Nacional para el Conocimiento y Uso de la Biodiversidad (CONABIO), Av. Liga Periférico-Insurgentes Sur 4903, Col. Parques del Pedregal, Tlalpan, 14010, Ciudad de México, México.

4 HRA, Identification and Naming, African Team, Herbarium, Royal Botanic Gardens, Kew, Richmond, Surrey, TW9 3AE, U.K.
} 